\title{
Optimalisasi Pengelolaan Limbah Tahu Menjadi Biogas Menuju Desa Mandiri Energi
}

\author{
Nanang Apriandi MS ${ }^{1 *}$, Lily Maysari Angraini ${ }^{2 *}$, Nurul Qomariyah ${ }^{2}$ \\ ${ }_{1}^{1}$ Program Studi D3 Konversi Energi, Jurusan Teknik Mesin, Politeknik Negeri Semarang, Jawa Tengah, Indonesia \\ 2 Program Studi Fisika, Fakultas Matematika dan Ilmu Pengetahuan Alam, Universitas Mataram, Nusa Tenggara Barat, Indonesia
}

DOI: https://doi.org/10.29303/ujcs.v2i1.25

\section{Article Info}

Received: January $28^{\text {th }}, 2021$
Revised: March 10th, 2021

Accepted: March 29th, 2021

\begin{abstract}
Abstrak: Optimalisasi pengelolaan limbah tahu di Desa Danger kemacatan Masbagik Kabupaten Lombok Timur sudah dilakukan. Desa danger merupakan desa yang menitikberakan sektor perekonomian warganya pada home indutrsi pembuatan tahu. Hampir 50\% dari total penduduk yang ada di desa tersebut menggeluti bidang ini. Limbah tahu, baik limbah padat maupun limbah cair, yang awalnya hanya dibuang begitu saja dan menimbulkan bau busuk, kini sudah diolah secara optimal menjadi biogas. Sumber energi baru ini dapat dimanfaatkan warga sebagai bahan bakar untuk produksi. TujuanKegiatan ini bertujuan untuk mrningkatkan keterampilan warga merancang dan membangun digester skala rumah tangga guna optimalisasi pengelolaan limbah tahu menjadi biogas. Metode kegiatan yang digunakan adalah focus discussion group untuk need assement permasalahan yang ada pada warga, dan kemudian transfer teknolgi biogas dengan cara memberikan pendampingan kepada warga sebagai mitra mulai dari pembuatan digester sampai pengelolaan slury sisa biogas. Hasil dari kegiatan ini adalah terbangunnya digester skala rumah tangga pada mitra dan meningkatnya pemahaman mitra terkait dengan pengelohan limbah tahu baik padat maupun cair untuk menjadi biogas serta terwujudnya konsep desa mandiri energi
\end{abstract}

Kata Kunci: Limbah tahu; biogas; desa mandiri energi.

Abstract: Optimization of tofu waste management in Danger Village masbagik kemacatan East Lombok district has been done. Danger village is a village that focuses its economic sector on home indutrsi tofu making. Almost 50\% of the total population in the village is involved in this field. Tofu waste, both solid waste and liquid waste, which was initially only disposed of and caused a foul smell, has now been optimally processed into biogas. This new energy source can be used by citizens as fuel for production. The purpose of this activity aims to improve the skills of citizens designing and building household-scale digesters in order to optimize the management of waste tofu into biogas. The method of activity used is focus discussion group to need assement problems that exist in the citizens, and then transfer biogas technology by providing assistance to citizens as partners ranging from digester making to slury management of biogas waste. The result of this activity is the establishment of household-scale digesters in partners and increased understanding of partners related to the use of waste tofu both solid and liquid to become biogas and the realization of the concept of energy independent villages

Keywords: Waste tofu; biogas; energy self-contained villages.

Citation: Apriandi, N., Angraini, L.M., Qomariyah, N., (2021). Optimalisasi Pengelolaan Limbah Tahu Menjadi Biogas Menuju Desa Mandiri Energi. Unram Journal of Community Service, 2(1), $29-32$. doi:https://doi.org/10.29303/ujcs.v2i1.25

\section{Pendahuluan}

Desa Danger terletak di wilayah kecamatan Masbagik Kabupaten Lombok Timur. Desa dengan luas wilayah sekitar $463 \mathrm{Ha}$ memiliki jumlah penduduk sekitar 1.6041 jiwa atau sekitar 500 kepala keluarga.
Sebagian besar warga desa Danger berprofesi sebagai pengusaha, pengrajin, dan peternak [Badan Pusta Statistik $(2018,2020)$.

Salah satu jenis usaha yang dilakukan di desa tersebut adalah home industry pembuatan tahu Badan Pusat Statistik $(2018,2020)$. Berdasarkan hasil survey 
yang diperoleh, jumlah bahan baku kedelai yang diolah menjadi tahu rata-rata setiap kepala keluarga berkisar 1-2 kwintal kedelai setiap harinya. Jumlah ini terus bertambah seiring dengan permintaan tahu yang semakin meningkat baik dari konsumen lokal maupun dari konsumen di luar daerah.

Secara ekonomi, pertumbuhan industri tahu memberikan dampak positif bagi peningkatan pendapatan penduduk desa Danger. Akan tetapi, tanpa disadari home industry ini menjadi salah satu penyumbang kadar COD (Chemical Oxigen Demand) yang cukup tinggi dan dapat menyebabkan pencemaran lingkungan yang cukup berat jika tidak dikelola dengan baik (Cowan \& Wolf, 1974).

Industri tahu dalam prosesnya menghasilkan limbah cair dan padat, (Kaswinarni, 2017). Pada prinsipnya terdapat delapan tahapan pembuatan tahu yaitu perendaman dan pencucian, penggilingan, pemasakan, penyaringan, penggumpalan, pemisahan tahu dari whey, dan pengepresan serta pemotongan (Kaswinarni, 2017).

Berdasarkan hasil wawancara dengan mitra sebagai pelaku industri, diperoleh kisaran perbandingan jumlah kedelai yang digunakan sebagai bahan baku dengan jumlah produksi tahu yang diperoleh. $1 \mathrm{~kg}$ kedelai dapat memproduksi tahu sekitar 3,3 kg dan ampas tahu sekitar $2.0 \mathrm{~kg}$.

Sedangkan limbah cair tahu berasal dari proses perendaman dan pencucian kedelai, dan dari proses pencetakan dan pengepresan tahu (disebut whey). Volume limbah cair industri tahu per kilogram kedelai yang diolah adalah sekitar 17 liter. Akan tetapi, volume ini akan berbeda, karena disebabkan karena perbedaan unit fasilitas produksi dan kebiasaan kerja antar daerah (Romli \& Suprihatin 2019).

Menurut Prihantoro, (2010) limbah cair tahu memiliki keasaman dengan $\mathrm{pH} 4-5$, COD berkisar $10.000 \mathrm{mg} /$ liter dan BOD $5.000 \mathrm{mg} /$ liter. Berdasarkan survey serta wawancara mitra, umumnya limbah cair tahu ini langsung dibuang ke sungai atau ke selokan.

Jika ini dibiarkan terus menerus, maka akan berdampak pada kematian organisme perairan karena kekurangan oksigen. Jika air sungai yang tercemar dialirkan ke sawah, maka limbah cair tahu akan menghasilkan gas metan yang menyebabkan unsur hara di dalam tanah menjadi tidak seimbang. Ketidakseimbangan ini menyebabkan bulir padi menjadi puso atau kosong.

Salah satu solusi yang dapat diterapkan untuk mengatasi masalah tersebut adalah model desa mandiri energi menuju kemandirian energi secara lokal. Salah satu pendekatan tim PKM adalah dengan meluncurkan program Desa Mandiri Energi: Pengelolaan limbah tahu menjadi biogas dan bisa diterapkan dalam skala rumah tangga. Konsep desa mandiri energi adalah konsep yang berpijak pada pemanfaatan energi terbarukan dan pemberdayaan masyarakat (Zali et al., 2017). Pada dasarnya, biogas ini merupakan salah satu teknologi alternatif energi terbarukan yang memiliki potensi besar untuk dikembangkan, disamping juga ramah lingkungan (Apriandi, et al, 2013; Sally et al, 2019; Chusniyah et al, 2019).

Desa Danger merupakan desa yang mengembangkan home industry tahu sebagai motor penggerak perekonomian. Hampir 50\% kepala keluarga mengelola home industri ini. Akan tetapi, pengelohan limbah home industri berupa limbah cair dan limbah padat, belum ditangani secara tepat. Hal ini disebakan karena kurangnya pengetahuan para pelaku industri tentang bagaimana cara pengolahan limbah tersebut. Selama ini, mereka hanya membuat saluran pembuangan limbah cair ke selokan, sungai dan terkadang ke sawah. Para pelaku industri tidak memahami dengan baik dampak kandungan kimia yang ada pada air limbah. Dimana, kandungan tersebut bisa merusak lingkungan sekitar dan menyebabkan turunnya kualitas air tanah.

Pengelolaan limbah tahu menjadi biogas merupakan alternatif metode yang digunakan untuk mengatasi hal tersebut. Metode ini sejalan dengan konsep desa mandiri energi berbasis biogas yang tengah dikembangkan oleh berbagai peneliti. Konsep tersebut membutuhkan dua kemampuan dasar yaitu pemanfaatan energi terbarukan dan pengembangan sumberdaya manusia.

Jika merujuk pada kondisi mitra yang minim pengetahuan tentang pengelolaan limbah tahu menjadi biogas, maka diperlukan pendampingan untuk mengintroduce tata cara pembuatan biogas berbasis limbah tahu.

Mitra yang merupakan pelaku industri tidak memiliki pengetahuan tata cara pengelolaan limbah tahu tahu yang dihasilkan. Limbah-limbah tersebut dibuang begitu saja, padahal produksi tahu terus menerus bertambah, dan tentu saja volume limbah yang dihasilkan pun terus menerus bertambah. Jika dibiarkan begitu saja, lingkungan sekitar mitra akan tercemar dan akan menimbulkan berbagai macam penyakit.

Disisi lain, konsep desa energi mandiri yang merupakan program yang akan dikembangkan oleh pemerintah kabupaten Lombok Timur juga harus didukung oleh pengelolaan sumber energi baru dan terbarukan serta pemberdayaan masyarakat. Oleh karena itu, tim PKM melaksanakan kegiatan pendampingan mitra untuk mengedukasi tata cara pengelolaan limbah tahu menjadi biogas. Mitra akan didampingi mulai dari proses pembuatan biogester, sampai pada proses pencampuran bahan baku biogas, mengecek apakah gas sudah dihasilkan serta 
pemanfaatan sisa slury menjadi pakan ternah atau pupuk kompos.

\section{Metode Pelaksanaan Kegiatan}

Metode yang digunakan dalam pelatihan pengelolaan limbah cair industri tahu menjadi biogas di desa Danger kecamatan Masbagik Lombok Timur adalah (1) Focus Group Discuss (FGD), (2) Transfer teknologi berupa pembuatan digester biogas, (3) Serta memberikan bantuan digester biogas perorangan sebagai nyata bahwa limbah cair tahu yang selama ini dibuang begitu saja dapat dimanfaatkan untuk energy alternatif skala rumah tangga dan juga untuk peningkatan kualitas produksi.

\section{Hasil dan Pembahasan}

\section{Focus Group Discussion}

Sebelum digester dibangun, dilakukan diskusi terlebih dahulu dengan para pelaku industri tahu di desa Danger kecamatan Masbagik. Diskusi yang sekaligus observasi yang dilakukan tim PKM berbasis door to door. Observasi dilakukan di lima kepala keluarga yang memproduksi minimal 1 kwintal kedelai setiap harinya.

Adapun hasil observasi yang diperoleh adalah pemberian bantuan pembuatan digester limbah cair tahu pada dasarnya pernah dilakukan oleh pemerintah daerah setempat secara kolektif. Pada awalnya limbah cairan yang diolah menjadi biogas dan pembangkit tenaga listrik alternatif berjalan dengan baik. Akan tetapi hal tersebut tidak berlangsung lama, penggunaan optimal yang bisa dirasakan manfaatnya oleh masyarakat setempat hanya 6 (enam) bulan.

Berdasarkan keterangan yang diberikan oleh masyarakat, terdapat beberapa penyebab digester tidak beroperasi lagi yaitu : (a) Pola bantuan koletif dan pemerintah setempat tidak menunjuk kelompok masyarakat yang bertanggung jawab terhadap mekanisme pengoperasian digester, sehingga digester dilepas begitu saja tanpa ada maintenance, (b) tidak adanya pelatihan atau penyuluhan tata cara pengoperasian digester, (c) limbah cair tahu yang ditampung di sumur penampungan yang telah dibuat dialirkan melalui pipa.

Karena limbah cair tahu yang dibuang memiliki suhu $100^{\circ} \mathrm{C}$ dengan kandungan garam dan asam yang tinggi. Hal ini menyebabkan korosi pada pipa pembuangan dan menyebabkan tidak lancarnya aliran air limbah tahu (mampet). Hal ini tidak diperhitungkan dengan matang pada saat pemasangan jenis pipa dan sebagainya. (d) selain, hasil diskusi dengan masyarakat setempat, mereka cenderung menginginkan bantuan digester yang sifatnya home by home. Alasannya adalah lebih memudahkan mereka dalam hal maintenance, dan mengelola limbah tahu untuk kebutuhan listrik ataupun kebutuhan bahan bakar unit produksi mereka masing-masing. Meskipun skalanya kecil tetapi lebih efesien dan lebih efektif.

Pola transfer energi cara pembuatan digester biogas serta praktek langsung di lapangan untuk pemanfaatan alat yang telah dibuat.

Berdasarkan hasil diskusi dan observasi tersebut di atas, maka tim memulai pembuatan digester biogas dengan cara langsung praktek di lapangan. Berikut hasil dokumentasi pmbuatan digester limbah cair tahu.

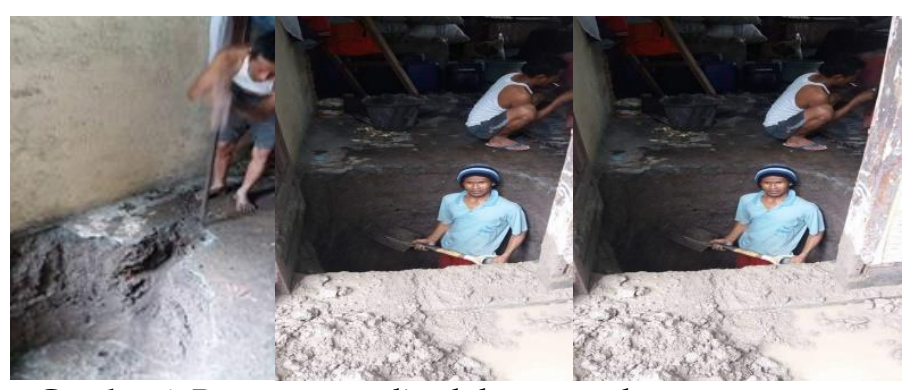

Gambar 1. Proses penggalian lubang untuk penananaman digester

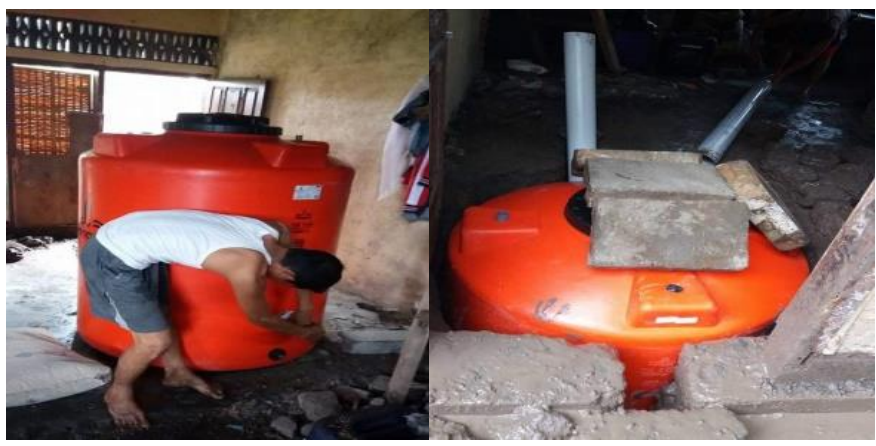

Gambar 2. Digester yang akan ditanam dan proses pembuatan lubang pipa ada digester

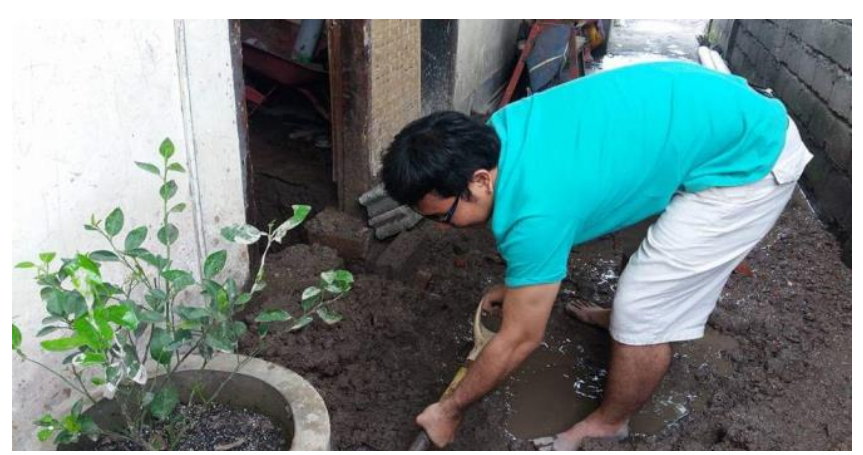

Gambar 3. Proses pembuatan saluran pembuangan residu 


\section{Kesimpulan}

Kegiatan ini dapat memberikan manfaat kepada masyarakat di desa Danger kecamatan Masbagik Lombok Timur, yaitu memberikan efesiensi penurunan beban pencemar pada masing-masing sistem pengelohan yang digunakan sehingga pada saat dibuang ke lingkungan, limbah cairnya telah memenuhi persyaratan baku mutu. Dengan demikian, kelestarian lingkungan dapat terjaga. Di sisi lain dapat menghasilkan nilai tambah energi dari biogas yang bermanfaat bagi pengrajin tahu di desa Danger.

\section{Daftar Pustaka}

Badan Pusat Statistik. (2018). Lombok Timur Dalam Angka. Lombok Timur.

Cowan J.C and Wolf W.J. (1974). Soybeans, Encyclopedia of food technology. The Avi Publishing Company, Inc. Westport, Connecticut. Volume 2, 818-828.

Kaswinarni, F. (2007). Kajian Teknis Pengelolaan Limbah Padat dan Cair Industri Tahu. Master thesis. Program Pascasarjana Universitas Diponegoro.

Romli, M., \& Suprihatin. (2009). Beban Pencemaran Limbah Cair Industri Tahu dan Analisis Alternatif Strategi Pengelolaannya. Jurnal Purifikasi, 10: 2, 141-154.

Prihantoro, E. (2010). Biogas dari Limbah Tahu. Kemenristekdikti.

Zali, M., Heryadi, A.Y., Irfan, M., Sukorini, H., Dyah, E,W. (2017). Model Desa Mandiri Energi: Demplot Biogas Dan Pupuk Organik. Prosiding Seminar nasional dan gelar produk Universitas Muhammadiyah Malang, yang diselenggarakan 17-18 Oktober 2017.

Apriandi, M.S, Wijaya I.G.B.K., Widiyarta, I.M. (2013). Pemurnian Biogas Terhadap Gas Pengotor Karbondioksida $\left(\mathrm{CO}_{2}\right)$ Dengan Teknik Absorbsi Kolom Manometer (Manometry Column). Jurnal Logic, 13(1).

Badan Pusat Statistik, (2020). Lombok Timur Dalam Angka. Lombok Timur

Sally, S., Yessica, P.B., Meutia, W.K., Warsono, E.K. (2019). Potensi Pemanfaatan Limbah Cair Tahu Menjadi Biogas Untuk Skala Industri Rumah Tangga Di Provinsi Banten. Jurnal Teknologi Industri Pertanian. 13. $1:$ 43-53.

Chusniyah, D.A., Pratiwi, R., Pudyastuti, K., Zabidi, L., Prima, P., Akbar, R., \& Sugiarti, L. (2019). Penyuluhan Pengolahan Limbah Cair Tahu Sebagai Energi Alternatif Biogas Di Pabrik Tahu Usaha Maju Pangan Suplai. Jurnal Abdi Masyarakat Indonesia, 1(2). 36-40. 